\title{
Irrigation Regimes Affect Cabbage Water Use and Yield
}

\author{
Doyle A. Smittle', W. Lamar Dickens ${ }^{1}$, and James R. Stansell ${ }^{2}$ \\ University of Georgia, Coastal Plain Experiment Station, Tifton, GA 31793
}

Additional index words. Brassica oleraceae, evaporation, evapotranspiration, irrigation scheduling, soil water tension, wateruse modeling

\begin{abstract}
Cabbage (Brassica oleracea L.) was grown in drainage lysimeters under controlled soil water regimes during 3 years. Three irrigation regimes were imposed on cabbage grown on two soil types during the spring and fall growing seasons. Irrigation regimes consisted of applying water when the soil water tension at $10 \mathrm{~cm}$ exceeded 25,50, or $75 \mathrm{kPa}$ during crop growth. Yields and water use were highest when irrigation was applied at $25 \mathrm{kPa}$ soil water tension. Regression equations are presented to describe the relationships of water use to plant age and to compute the ratios of daily evapotranspiration to pan evaporation (crop factors) for cabbage grown under the three irrigation regimes.
\end{abstract}

Cabbage has been classified as intermediately susceptible to water stress, with the head formation period being more sensitive than the period before (Bruce et al., 1980; Janes, 1950; Nortje and Henrico, 1988: Singh and Alderfer, 1966). Vittum et al. (1963) reported that the most critical irrigation period occurred during the last 3 to 4 weeks before harvest. In this study, the soil was often near field capacity when the plants were set in the field in the northeastern United States, and normal rainfall usually supplied the low water-use needs of small plants. Singh and Alderfer (1966) also found that marketable yields of cabbage were similar when irrigations were applied at $100 \mathrm{kPa}$ soil water tension during growth and when cabbage was irrigated at $1000 \mathrm{kPa}$ before head formation and $100 \mathrm{kPa}$ after head formation. However, when cabbage was irrigated at $100 \mathrm{kPa}$ before head formation and at $1000 \mathrm{kPa}$ after head formation, marketable yields were similar to cabbage irrigated at $1000 \mathrm{kPa}$ soil water tension during growth. Yields of cabbage produced during the winter in Texas were similar when irrigated at $80 \mathrm{kPa}$ and $160 \mathrm{kPa}$ soil water tension, but irrigating at a soil water tension of $360 \mathrm{kPa}$ reduced yields (Thomas et al., 1970).

Yields have been reduced substantially when the soil water tension was $>25 \mathrm{kPa}$ before many drought-sensitive vegetables were irrigated (Bruce et al., 1980; Smittle et al., 1990b, 1992b; Stansell and Smittle, 1980, 1989); therefore, cabbage yields may have been higher than reported earlier (Singh and Alderfer, 1966; Thomas et al., 1970) if the crop receiving the low-stress treatment had been irrigated at 25 rather than 80 or $100 \mathrm{kPa}$ soil water tension. Drew (1966) reported higher cabbage yields with irrigation at $12.5 \%$ than at $25 \%, 50 \%$, or $75 \%$ available soil moisture. He also reported that irrigation during the last 2 to 3 weeks substantially increased yields of stressed and nonstressed cabbage, while irrigation during the earlier part of the season had little effect on yields.

A consumptive use requirement of $380 \mathrm{~mm}$ of water for producing high cabbage yields was about the same for trickle, modified-furrow, and standard-furrow irrigation methods (Bucks et al., 1974), but applying water at less than the consumptive use rate reduced yields. Water-use rates for cabbage were further

Received for publication 21 Aug. 1992. Accepted for publication 25 May 1993 Supported by state and Hatch Act funds allocated to the Georgia Agricultural Experiment Stations and the Richard King Mellon Foundation. The cost of publishing this paper was defrayed in part by the payment of page charges. Under postal regulations, this paper therefore must be hereby marked advertisement solely to indicate this fact.

'Dept. of Horticulture.

${ }^{2}$ Dept. of Agricultural Engineering. defined by Nelson and Hwang (1976) in a greenhouse growthchamber experiment. The transpiration rate under controlled conditions varied with plant age. Daily transpiration, increased from $80 \mathrm{~g}$ at 40 days after planting seeds (DAP) to $\approx 300 \mathrm{~g}$ at head formation (60 DAP), reached a peak use of $\approx 355 \mathrm{~g}$ at $75 \mathrm{DAP}$, then decreased to $325 \mathrm{~g}$ at $105 \mathrm{DAP}$. The growth chambers did not circulate air; therefore, an important factor influencing evapotranspiration (ET) under field conditions was not considered.

Several methods of estimating ET from climatic data have been developed. The modified Penman and the Jensen-Haise methods use combinations of solar radiation, temperature, humidity, wind velocity, and vapor-pressure measurements to estimate the ET of a reference crop, then use a crop coefficient to adjust the ET value estimated for the reference crop to estimate the ET of the crop to be irrigated (Hansen et al., 1980), The crop coefficient values (ET of the irrigated crop/ET of reference crop) are multiplied by the ET value estimated by the specific method to estimate the ET of the irrigated crop.

Pan evaporation $\left(\mathrm{E}_{\mathrm{p}}\right)$ incorporates the climatic factors influencing ET into a single measurement (Hansen et al., 1980) and has been used to schedule irrigation for several crops (Jensen and Middleton, 1970). The single crop factor value $\left(\mathrm{ET} / \mathrm{E}_{\mathrm{p}}\right)$ used by Jensen and Middleton (1970) usually resulted in applying excessive water during some growth periods and water deficits during other growth periods. A generalized curve was presented to describe crop factor value changes during crop development (Hansen et al., 1980), but the generalized curve lacks precision. We have developed regression equations to calculate daily crop factor values during the growth of several vegetables (Stansell and Smittle, 1980, 1989; Smittle et al., 1992b, 1990b) and have incorporated these equations to estimate $\mathrm{ET}$ from $\mathrm{E}_{\mathrm{p}}$ data into irrigation scheduling models (Smittle and Dickens, 1992; Smittle, et al., 1990a, 1992a).

In this research, we determined the yield and water-use responses of cabbage to three irrigation regimes. We also developed regression equations to calculate crop factors during growth of cabbage grown under the various irrigation regimes.

\section{Materials and Methods}

During Spring 1982 and Fall 1983 and 1985, 'Rio Verde' cabbage was grown in lysimeters containing a Tifton loamy sand soil and a Bonifay sand soil. The Bonifay sand was composed of 92. $1 \%$ sand, $2.0 \%$ silt, $4.1 \%$ clay, and $1.8 \%$ organic matter. The Tifton loamy sand was composed of $80.4 \%$ sand, $9.0 \%$ silt, $7.0 \%$ 
clay, and $3.6 \%$ organic matter. The lysimeter plots were equipped with automatic rainfall shelters activated by rainfall (Stansell and Smittle, 1980). A combination of between-plot moisture barriers (1.2 $\mathrm{m}$ deep) and subsurface drains was used to isolate the plots from each other and from groundwater intrusion. Each shelter protected 24 plots, $1.5 \times 1.8-\mathrm{m}$ of a single soil type. Each plot contained six resistance-block soil-moisture sensors placed 10,23,38,53,81, and $107 \mathrm{~cm}$ deep. The sensors were read daily beginning at $0800 \mathrm{HR}$ by a data-collection system controlled by an on-site computer. The data were processed by the computer and a daily report, which included the soil water content at each sensor depth and the irrigation requirements for the day, was printed. Soil water data were stored for future analyses. Each shelter contained 12 plots of cabbage.

For 10 to 14 days after transplanting, water was applied with a hand-held sprinkler nozzle. After this time, irrigation was scheduled by measured soil water deficits. Irrigation treatments within the 5 year-season-soil type combinations were arranged in a randomized complete-block design with four replications. Treatments consisted of irrigating at soil water tensions of 25,50, or 75 $\mathrm{kPa}$. When sensors $10 \mathrm{~cm}$ deep showed soil water deficit corresponding to the treatment requirements, water was applied to refill the surface $30 \mathrm{~cm}$ of the soil profile to field capacity $(8 \mathrm{kPa})$. The amount of water applied represented the average of the four replications and was determined from water retention curves for the soil (Stansell and Smittle, 1980).

Climatological data, including rainfall, open pan evaporation, wind movement, relative humidity, and maximum and minimum air temperatures were collected daily at the research site.

Plots were hand-tilled to incorporate fertilizers applied at $67 \mathrm{~N}-$ 49P-124K (in $\mathrm{kg} \cdot \mathrm{ha}^{-1}$ ). Transplants were set by hand on $1 \mathrm{Mar}$. 1982, 2 Sept. 1983, and 24 Sept. 1985. Plants were spaced $30 \mathrm{~cm}$ apart in $91 \mathrm{~cm}$ rows. Nitrogen was broadcast at $34 \mathrm{~kg} \cdot \mathrm{ha}^{-1}, 3,5$, and 7 weeks after transplanting.

Plots were harvested on 14,17, and 20 May 1982, on 16,22, and
28 Nov. 1983, and on 11 Nov. and 2 and 11 Dec. 1985. The number and weight of total and marketable cabbage heads were determined. Yield data for the irrigation regimes were subjected to regression analyses wherein the 5-year-season-soil type combinations were considered as separate experiments.

We assumed that water applied would be a valid estimate of water use or ET, since these plots were protected from rainfall and groundwater intrusion and water was added based on water content at various depths in the soil profile. Sufficient water (50 to $75 \mathrm{~mm}$ ) was applied during the first 10 days after transplanting to recharge the soil profile. Data for the initial water applications and pan evaporation during these periods were not included in the calculation of ET and evaporation rates, since the amount of water applied at the last irrigation would also recharge the soil profile. Daily water-use (ET) rates were determined by dividing the depth of water applied to each plot at each irrigation by the number of days since the last irrigation. Daily $\mathrm{E}_{\mathrm{p}}$ rates were calculated by dividing the sum of the $E_{p}$ depths between irrigations by the number of days over which the age data were accumulated. Data for ET and $\mathrm{E}_{\mathrm{p}}$ rates on the irrigation date were used to calculate daily $\mathrm{ET} / \mathrm{E}_{\mathrm{p}}$ values. Regression equations were developed to describe changes in ET, $\mathrm{E}_{\mathrm{p}}$, and $\mathrm{ET} / \mathrm{E}_{\mathrm{p}}$ with age using SAS's general linear models procedure (SAS Institute, 1982).

\section{Results and Discussion}

When averaged over the five crops, $99.4 \%, 96.2 \%$, and $95.2 \%$ of the total yield of cabbage irrigated at 25,50 , and $75 \mathrm{kPa}$, respectively, were marketable. Therefore, only marketable yields are presented (Table 1). Marketable yields of cabbage from each of the five crops were highest when irrigation was applied at a soil water tension of $25 \mathrm{kPa}$. Marketable yield of all crops except the crop grown on the Tifton soil in spring 1982 decreased linearly with increasing water stress. Significant quadratic yield responses

Table 1. Effect of irrigation regime on marketable yields of 'Rio Verda' cabbage during spring and fall production seasons on Tifton loamy sand and Bonifay sand soils.

\begin{tabular}{lcccc}
\hline \hline & \multicolumn{3}{c}{ Marketable yield $\left(\mathrm{t} \cdot \mathrm{ha}^{-1}\right)$} \\
\cline { 2 - 4 } & \multicolumn{3}{c}{ Irrigation regime $(\mathrm{kPa})^{\mathrm{z}}$} & \\
\cline { 2 - 5 } Year-season-soil & 25 & 50 & $\mathbf{7 5}$ & Significance \\
\hline 1982-Spring-Tifton & 47.6 & 38.6 & 48.6 & $\mathrm{Q}^{* * *}$ \\
1982-Spring-Bonifay & 51.2 & 45.0 & 40.6 & $\mathrm{~L}^{* *}$ \\
1983-Fall-Bonifay & 42.9 & 39.1 & 35.5 & $\mathrm{~L}^{*}$ \\
1985-Fall-Tifton & 43.7 & 35.4 & 34.0 & $\mathrm{~L}^{*} \mathrm{Q}^{* *}$ \\
1985-Fall-Bonifay & 42.4 & 39.2 & 35.4 & $\mathrm{~L}^{* *}$ \\
\hline
\end{tabular}

${ }^{\mathrm{z} P l o t s}$ were irrigated when soil water tension at $10 \mathrm{~cm}$ was 25,50 , or $75 \mathrm{kPa}$.

*.** Significant at $P \leq 0.05$ or $0.01 ; \mathrm{L}=$ linear, $\mathrm{Q}=$ quadratic.

Table 2. Effect of production season and soil type on pan evaporation and water use by 'Rio Verda' cabbage grown under three irrigation regimes.

\begin{tabular}{lcccc}
\hline \hline & \multirow{2}{*}{$\begin{array}{c}\text { Pan } \\
\text { evaporation }\end{array}$} & \multicolumn{3}{c}{${\text { Water applied }(\mathrm{mm})^{\mathrm{z}}}^{\text {Irrigation regime }(\mathrm{kPa})^{\mathrm{y}}}$} \\
\cline { 3 - 5 } Year-season-soil & $(\mathrm{mm})$ & 25 & 50 & 75 \\
\cline { 3 - 5 } 1982-Spring-Tifton & 270 & $175(14)$ & $182(11)$ & $153(8)$ \\
1982-Spring-Bonifay & 270 & $177(17)$ & $158(10)$ & $142(8)$ \\
1983-Fall-Bonifay & 233 & $146(13)$ & $111(9)$ & $131(8)$ \\
1985-Fall-Tifton & 131 & $82(12)$ & $84(8)$ & $71(8)$ \\
1985-Fall-Bonifay & 131 & $84(8)$ & $75(6)$ & $74(7)$ \\
\hline
\end{tabular}

${ }^{\mathrm{z}}$ Numbers in parentheses are the number of irrigations applied to each irrigation regime.

yPlots were irrigated when soil water tension at $10 \mathrm{~cm}$ was 25,50 , or $75 \mathrm{kPa}$. 
to irrigation regime for cabbage grown on Tifton loamy sand during Spring 1982 and Fall 1985 were due to a large increase in total yield with irrigation at a soil water tension of $25 \mathrm{kPa}$. These data suggest that cabbage is more sensitive to water stress than reported earlier (Janes, 1950; Singh and Alderfer, 1966) when grown on the shallow, low water-holding-capacity soils of the southeastern Coastal Plain.

In 1982 and 1985, yields of cabbage grown on the two soil types were similar. Summer squash (Cucurbita pepo L.) yields also were not affected by soil type when grown in these rainfall shelters (Stansell and Smittle, 1989).

$\mathrm{E}_{\mathrm{p}}$ was 16\% and 106\% greater during cabbage growth in Spring 1982 than in Fall 1983 and 1985, respectively (Table 2). During the 10 to 83 days after transplanting when water applications were determined by soil water tension $10 \mathrm{~cm}$ deep, 7 to 14 irrigations were required to maintain the maximum soil water tensions below the desired level. Water applied to the cabbage crops varied among the years, but the amount of water applied within a growing season was similar for cabbage grown on the Tifton loamy and Bonifay sand soils in 1982 and 1985. The amount of water applied at each irrigation decreased as the soil water tensions at irrigation decreased from 75 to $25 \mathrm{kPa}$, but less total water was usually applied to cabbage that was subjected to water stress of 75 and 50 than 25 $\mathrm{kPa}$ soil water tension. These results follow the general trend that water use is increased by more frequent irrigation to crops grown under the same climatic conditions (Bruce et al., 1980; Stansell and Smittle, 1980, 1989). Marketable yields per millimeter of water applied were $0.34,0.32$, and $0.32 \mathrm{t} \cdot \mathrm{ha}^{-1}$ for cabbage irrigated at soil water tensions of 25,50 , and $75 \mathrm{kPa}$, respectively.

ET and $E_{\mathrm{p}}$ data for the growth period between 10 days after transplanting until the last irrigation were used to develop regression equations to describe $\mathrm{E}_{\mathrm{p}}, \mathrm{ET}$, and $\mathrm{ET} / \mathrm{E}_{\mathrm{p}}$ values. Daily $\mathrm{E}_{\mathrm{p}}$ rates varied from 0 to $7 \mathrm{~mm}$ during the 3 to 10 days of water use between irrigations; however, the $\mathrm{E}_{\mathrm{p}}$ rates generally decreased during growth of the fall cabbage crop. The combination of a variation in total potential ET among the five tests and the differences in growth stage at which maximum potential ET occurred contributed to the variation in ET described by the regression equations for ET per day (Table 3). The quadratic regression equations for ET accounted for $82 \%$ to $97 \%$ of the variation in daily ET with age, as seen by the $r^{2}$ values. The relationships between ET and crop age were closer for the two spring than for the three fall cabbage crops. The daily ET relationships were less close when the five cabbage crops were combined than when either the spring or fall cabbage crops were included in separate regression analyses. The high percentage ( $82 \%$ to $84 \%$ ) of variation in ET by the five cabbage crops described by the quadratic regression equations indicate that crop age has a dominant effect on the change of cabbage ET, as indicated by Nelson and Hwang (1976). Our results suggest that using the quadratic regression equations to estimate daily cabbage ET would accurately estimate the number of days between irrigations if climatic conditions were similar to those during these tests.

$\mathrm{ET} / \mathrm{E}_{\mathrm{p}}$ values provide a method of adjusting these daily ET values to compensate for variations in the climatic conditions that influence ET. Jensen and Middleton (1970) expressed ET/E $\mathrm{E}_{\mathrm{p}}$ as a constant relationship between ET and $\mathrm{E}_{\mathrm{p}}$. Our earlier research (Smittle et al., 1990b, 1992b) shows that the relationship of ET to age changes with crop age. In this study, the regression equations to describe daily ET/ $\mathrm{E}_{\mathrm{p}}$ values accounted for $96 \%$ to $99 \%$ of the variations of $\mathrm{ET} / \mathrm{E}_{\mathrm{p}}$ for the three irrigation regimes of the five

Table 3. Effect of production season and soil-type on regression equations to describe daily water use (millimeters per day) change with age (A) of 'Rio Verda' cabbage grown under three irrigation regimes.

\begin{tabular}{lcccccc}
\hline & $r^{2}$ & Regression & $r^{2}$ & Regression & $r^{2}$ & Regression \\
\cline { 2 - 7 } & \multicolumn{5}{c}{ Irrigation Regime $(\mathrm{kPa})^{2}$} \\
\cline { 2 - 7 } Year-season-soil & \multicolumn{2}{c}{25} & 50 & 75 \\
\hline 1982-Spring-Tifton & 0.91 & $0.133 \mathrm{~A}-0.00101 \mathrm{~A}^{2}$ & 0.97 & $0.086 \mathrm{~A}-0.00027 \mathrm{~A}^{2}$ & 0.94 & $0.086 \mathrm{~A}-0.00052 \mathrm{~A}^{2}$ \\
1982-Spring-Bonifay & 0.94 & $0.078 \mathrm{~A}-0.00024 \mathrm{~A}^{2}$ & 0.85 & $0.081 \mathrm{~A}-0.00033 \mathrm{~A}^{2}$ & 0.97 & $0.066 \mathrm{~A}-0.00024 \mathrm{~A}^{2}$ \\
1983-Fall-Bonifay & 0.91 & $0.107 \mathrm{~A}-0.00106 \mathrm{~A}^{2}$ & 0.97 & $0.115 \mathrm{~A}-0.00124 \mathrm{~A}^{2}$ & 0.95 & $0.097 \mathrm{~A}-0.00092 \mathrm{~A}^{2}$ \\
1985-Fall-Tifton & 0.91 & $0.066 \mathrm{~A}-0.00060 \mathrm{~A}^{2}$ & 0.85 & $0.088 \mathrm{~A}-0.00098 \mathrm{~A}^{2}$ & 0.92 & $0.071 \mathrm{~A}-0.00078 \mathrm{~A} \mathrm{~A}^{2}$ \\
1985-Fall-Bonifay & 0.96 & $0.082 \mathrm{~A}-0.00094 \mathrm{~A}^{2}$ & 0.98 & $0.052 \mathrm{~A}-0.00044 \mathrm{~A}^{2}$ & 0.98 & $0.059 \mathrm{~A}-0.00057 \mathrm{~A}^{2}$ \\
Spring crops & 0.92 & $0.105 \mathrm{~A}-0.00061 \mathrm{~A}^{2}$ & 0.92 & $0.087 \mathrm{~A}-0.00069 \mathrm{~A}^{2}$ & 0.91 & $0.076 \mathrm{~A}-0.00039 \mathrm{~A}^{2}$ \\
Fall crops & 0.87 & $0.084 \mathrm{~A}-0.00083 \mathrm{~A}^{2}$ & 0.89 & $0.090 \mathrm{~A}-0.00096 \mathrm{~A}^{2}$ & 0.89 & $0.071 \mathrm{~A}-0.00066 \mathrm{~A}^{2}$ \\
All crops & 0.82 & $0.093 \mathrm{~A}-0.00068 \mathrm{~A}^{2}$ & 0.84 & $0.096 \mathrm{~A}-0.00091 \mathrm{~A}^{2}$ & 0.83 & $0.075 \mathrm{~A}-0.00056 \mathrm{~A}^{2}$
\end{tabular}

2Plots were irrigated when soil water tension at $10 \mathrm{~cm}$ was 25,50 , or $75 \mathrm{kPa}$.

Table 4. Effect of production season and soil type on regression equations to describe crop factor change with age (A) of 'Rio Verda' cabbage grown under three irrigation regimes.

\begin{tabular}{|c|c|c|c|c|c|c|}
\hline & $r^{2}$ & Regression & $r^{2}$ & Regression & $r^{2}$ & Regression \\
\hline & \multicolumn{6}{|c|}{ Irrigation regime $(\mathrm{kPa})^{\mathrm{z}}$} \\
\hline Year-season-soil & & 25 & & 50 & & 75 \\
\hline 1982-Spring-Tifton & 0.97 & $0.029 \mathrm{~A}-0.00026 \mathrm{~A}^{2}$ & 0.98 & $0.022 \mathrm{~A}-0.00016 \mathrm{~A}^{2}$ & 0.96 & $0.022 \mathrm{~A}-0.00018 \mathrm{~A}^{2}$ \\
\hline 1982-Spring-Bonifay & 0.98 & $0.021 \mathrm{~A}-0.00016 \mathrm{~A}^{2}$ & 0.98 & $0.019 \mathrm{~A}-0.00013 \mathrm{~A}^{2}$ & 0.98 & $0.019 \mathrm{~A}-0.00015 \mathrm{~A}^{2}$ \\
\hline 1983-Fall-Bonifay & 0.99 & $0.025 \mathrm{~A}-0.00019 \mathrm{~A}^{2}$ & 0.98 & $0.027 \mathrm{~A}-0.00023 \mathrm{~A}^{2}$ & 0.99 & $0.024 \mathrm{~A}-0.00012 \mathrm{~A}^{2}$ \\
\hline 1985-Fall-Tifton & 0.97 & $0.024 \mathrm{~A}-0.00019 \mathrm{~A}^{2}$ & 0.97 & $0.026 \mathrm{~A}-0.00019 \mathrm{~A}^{2}$ & 0.96 & $0.024 \mathrm{~A}-0.00016 \mathrm{~A}^{2}$ \\
\hline 1985-Fall-Bonifay & 0.98 & $0.027 \mathrm{~A}-0.00028 \mathrm{~A}^{2}$ & 0.98 & $0.024 \mathrm{~A}-0.00016 \mathrm{~A}^{2}$ & 0.96 & $0.021 \mathrm{~A}-0.00015 \mathrm{~A}^{2}$ \\
\hline Spring crops & 0.97 & $0.025 \mathrm{~A}-0.00021 \mathrm{~A}^{2}$ & 0.98 & $0.021 \mathrm{~A}-0.00015 \mathrm{~A}^{2}$ & 0.97 & $0.021 \mathrm{~A}-0.00016 \mathrm{~A}^{2}$ \\
\hline Fall crops & 0.97 & $0.025 \mathrm{~A}-0.00021 \mathrm{~A}^{2}$ & 0.97 & $0.025 \mathrm{~A}-0.00019 \mathrm{~A}^{2}$ & 0.97 & $0.023 \mathrm{~A}-0.00017 \mathrm{~A}^{2}$ \\
\hline All crops & 0.97 & $0.025 \mathrm{~A}-0.00021 \mathrm{~A}^{2}$ & 0.97 & $0.023 \mathrm{~A}-0.00017 \mathrm{~A}^{2}$ & 0.97 & $0.022 \mathrm{~A}-0.00017 \mathrm{~A}^{2}$ \\
\hline
\end{tabular}

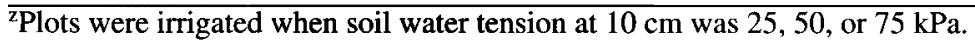


cabbage crops (Table 4). The similarity of regression equations for the crop irrigation regime combinations indicates that much of the variation in water-use estimates due to climatic differences was eliminated. Further, the close agreement of the equations within the $25-, 50-$, and $75-\mathrm{kPa}$ irrigation regimes when spring, fall, or all crops were combined suggests that daily ET/E $\mathrm{E}_{\mathrm{p}}$ values from these quadratic equations accurately estimate ET when multiplied by the measured $\mathrm{E}_{\mathrm{p}}$

We have shown that total and marketable cabbage yields were highest with irrigation applications when the soil water tension at 10 $\mathrm{cm}$ was $<25 \mathrm{kPa}$. This irrigation regime also required more water, but had a water-use efficiency rate similar to that of cabbage irrigated at soil water tensions of 50 and $75 \mathrm{kPa}$. Regression equations were developed to compute daily ET and $\mathrm{ET} / \mathrm{E}_{\mathrm{p}}$ values during cabbage growth. These equations allow $\mathrm{E}_{\mathrm{p}}$ to be adjusted daily so that it can be used to develop irrigation scheduling models (Smittle and Dickens, 1992; Smittle et al., 1990a, 1992a).

\section{Literature Cited}

Bruce, R. R., J.L. Chesness, T.C. Keisling, J.E. Pallas, Jr., D.A. Smittle, J.R. Stansell, and A.W. Thomas. 1980. Irrigation of crops in the southeastern United States: Principles and practices. U.S. Dept. Agr., Sci. Educ. Admin. Agr. Rev. Man. ARM-S-9.

Bucks, D.A., L.J. Erie, and O. French. 1974. Quantity and frequency of tickle and furrow irrigation for efficient cabbage production. Agron. J. 66(1):53-57.

Drew, D.H. 1966. Irrigation studies on summer cabbage. J. Hort. Sci. 41:103-114.

Hansen, V. E., O. W. Israelsen, and G.E. Stringham 1980. Irrigation principles and practices. 4th ed. Wiley, New York.

Janes, B.E. 1950. The effect of irrigation, nitrogen level and season on the composition of cabbage. Plant Physiol. 25:441-452.

Jensen, M.E. and J.E. Middleton. 1970. Scheduling irrigation from pan evaporation. Washington State Univ. Agr. Expt. Sta. Circ. 527.

Nelson, S.H. and K.E. Hwang. 1976. Water usage by cabbage plants at different stages of growth. Can. J. Plant Sci. 56:563-566.

Nortje, P.F. and P.J. Henrico. 1988. The effects of suboptimal irrigation and intra-row spacing on the yield and quality of cabbages. Acta Hort. 228: $163-170$

SAS Institute. 1982. SAS user's guide: Statistics. SAS Institute, Cary, N.C.

Singh, R. and R.B. Alderfer. 1966. Effects of soil-moisture stress at different periods of growth of some vegetable crops. Soil Sci. 101:69-80.

Smittle, D.A. and W.L. Dickens. 1992. Water budgets to schedule irrigation for vegetables. HortTechnology 2:54-59.

Smittle, D. A., W.L. Dickens, and M.J. Hayes. 1992a. An irrigation scheduling model for summer squash. J. Amer. Soc. Hort. Sci. 117:717-720.

Smittle, D. A., W.L. Dickens, and J.R. Stansell. 1990a. An irrigation scheduling model for snap beans. J. Amer. Soc. Hort. Sci. 115:226-230.

Smittle, D. A., W.L. Dickens, J.R. Stansell, and E. Simonne. 1992b.

Irrigation regimes affect leaf yield and water use by turnip and mustard. HortScience 27:308-310.

Smittle, D. A., M.R. Hall, and J.R. Stansell. 1990b. Effects of irrigation regimes on yield and water use by sweetpotato. J. Amer. Soc. Hort. Sci. 115:712-714

Stansell, J.R. and D.A. Smittle. 1980. Effects of irrigation regimes on yield and water use of snap beans (Phaseolus vulgaris L.). J. Amer. Soc. Hort. Sci. 105:869-873.

Stansell, J.R. and D.A. Smittle. 1989. Effects of irrigation regimes on yield and water use of summer squash. J. Amer. Soc. Hort. Sci. 114:196-199.

Thomas, J.R.,L.N. Namken and R.G. Brown. 1970. Yield of cabbage in relation to nitrogen and water supply. J. Amer. Soc. Hort. Sci., 95:732-735.

Vittum, M. T., R.B. Alderfer, BE. Janes, C.W. Renolds, and R.A. Structemeyer. 1963. Crop responses to irrigation in the Northeast. New York Agr. Expt. Sta., Geneva. Bul. 800. 